\title{
DOI: https://doi.org/10.24297/jaa.v10i0.8425
}

\section{Aavirulence and Antimicrobial Characteristics of Escherichia Coli Isolated from Diseased Chickens in China and Algeria}

\author{
Junwei Wang ${ }^{\star 1,2+}$, Ge Zhao ${ }^{1,2+}$, Yubin Gao ${ }^{1,3+}$, Hefei Xu4, Lounis Mohamed ${ }^{5}$, Jianmei Zhao ${ }^{1,2}$, Wenyan Gai ${ }^{1,2}$, \\ Ming Zou ${ }^{3}$, Zhigang Cui ${ }^{6}$, Shigan Yan ${ }^{7}$, Juan Wang ${ }^{1,2}$, Zhina Qu ${ }^{1,2}$ \\ ${ }^{1}$ Laboratory of Pathogenic Microorganism Inspection, China Animal Health and Epidemiology Center, Qingdao \\ 266032, China; \\ 2.Laboratory for Quality \& Safety Risk Assessment of Livestock and Poultry Products, Ministry of Agriculture \\ and Rural Affairs, Qingdao 266032, China; \\ 3.College of Veterinary Medicine, Qingdao Agricultural University, Qingdao 266109, China; \\ ${ }^{4}$ Qingdao International Travel Healthcare Center, Qingdao 266071, China;
}

5.Faculté des Sciences de la Nature et de la Vie, Université Ziane Achour, BP 3117, Route de Moudjbara, 17000 Djelfa, Algeria;

6.Chinese Center for Disease Control and Prevention, Beijing 102206, China;

${ }^{7}$ School of Bioengineering, Qilu University of Technology, Jinan 250353, China

Corresponding author Email: yffs2000@sina.com

* Corresponding author + Equal contributors

\begin{abstract}
To reveal and compare the prevalence of pathotypes and virulence genes, as well as antimicrobial resistance and genotyping of poultry E. coli isolates from China and Algeria. Pathotype and seven virulence genes were tested by PCR, susceptibility to antimicrobials was evaluated using broth microdilution method, and genotyping was analyzed by PFGE. Six isolates were identified as pathogenic E. coli. Virulence gene testing showed that the frequency of ompT, iss, fimc, iroN, hlyF, and iutA was high in the isolates from Shandong, Shanxi, Jiangsu, and Xinjiang province, while st 2 was detected in only two isolates from Shandong, and stx2, iss, fimC, hlyF, and iutA could not be detected in Tibet isolates. Importantly, nearly all isolates from Algeria carried seven virulence genes. Drug resistance testing of 141 strains showed that 98.2\% (109/111) of the isolates from China and all isolates (30/30) from Algeria resist to more than three classes of antimicrobials. The PFGE genotyping of 157 isolates yielded 134 types, demonstrated a high level of genetic diversity among these isolates. Thus, the poultry E. coli from both China and Algeria exhibited either high frequencies of antimicrobial resistance or high rates of virulence genes carrying.
\end{abstract}

Keywords: Pathogenic Characteristic, Antimicrobial Resistance, Virulence Gene, Genotyping, Poultry E. Coli. 


\section{Introduction}

Escherichia coli (E. coli) is a member of the normal flora in human and warm-blooded animal intestinal tracts. Nevertheless, some E. coli strains are usually pathogenic and have virulence properties that may cause animal diarrhea, hemorrhagic colitis and hemolytic uremic syndrome [1]. Certain strains can even cause public health problems, including life-threatening infections. Up to now, five kinds of E. coli pathotype are widely recognized that may cause colibacillosis both in human and animals according to their specific virulence gene, pathogenic mechanism and genetic features: enteropathogenic E. coli (EPEC), Shiga toxin-producing E. coli (STEC), enterotoxigenic E. coli (ETEC), enteroinvasive E. coli (EIEC) and enteroaggregative E. coli (EAEC) [2]. The pathogenic E. coli generally possesses rich virulence genes that displayed during disease happening. However, many clinical isolated E. coli strains from diseased or dead chickens may carried abundant virulence genes but cannot attribute to any pathotype.

Pulsed-field gel electrophoresis (PFGE) is a DNA based genetic fingerprinting tool that can preferably differentiate strains by comparing genotypic characteristics. This method has been recently used to estimate the source of Salmonella spp. contamination in poultry products [3], analyze the similarity of E. coli strains isolated from different poultry slaughterhouses [4], as well as identify the route and origin of infection for specifying bacteria that may be responsible for a food-borne illness earlier [5].

Currently, the rising of antimicrobial resistance, especially the emergence of multidrug-resistance (MDR), has become a common public health concern, in particular the abuse and misuse of antibacterials in broiler population. One of the main causes of the MDR strains emerging is bacteria acquired and disseminated exogenous genes by mobile genetic elements [6]. The sustained growth of avian origin E. coli isolates with MDR phenotypes has been published frequently $[4,5,7,8]$.

Though there were some pathogenic or drug resistance characteristic analysis of E. coli isolated from poultry in China or Algeria earlier $[4,9,10]$, few studies have supplied sufficient comparison information of avian origin $E$. coli strains isolated from representative provinces in China and western African countries. Thus, in this study, we designed to show the prevalence of pathotypes and virulence genes, as well as the antimicrobial characteristics of $E$. coli isolated from diseased and/or freshly died chickens in different regions of China. Furthermore, we compared them with counterpart of Algeria so as to seek their genetic similarities and differences.

\section{Materials and Methods}

\section{Isolations of E. coli}

In this study, a total of 248 strains were ananlyzed, including 30 strains confirmed as E.coli from freshly died broiler chickens in Algeria previously [9]. All Chinese strains were isolated from diseased poultry population or freshly dead chickens in seven representative provinces by local animal hygiene department in 2017 (Fig 1). All isolates were confirmed to be E. coli using API 20E biochemical test strips (bioMérieux, France). Sorbitol fermentation characteristic was examined using sorbitol-MacConkey agar (SM-AC) (Oxoid, UK). 


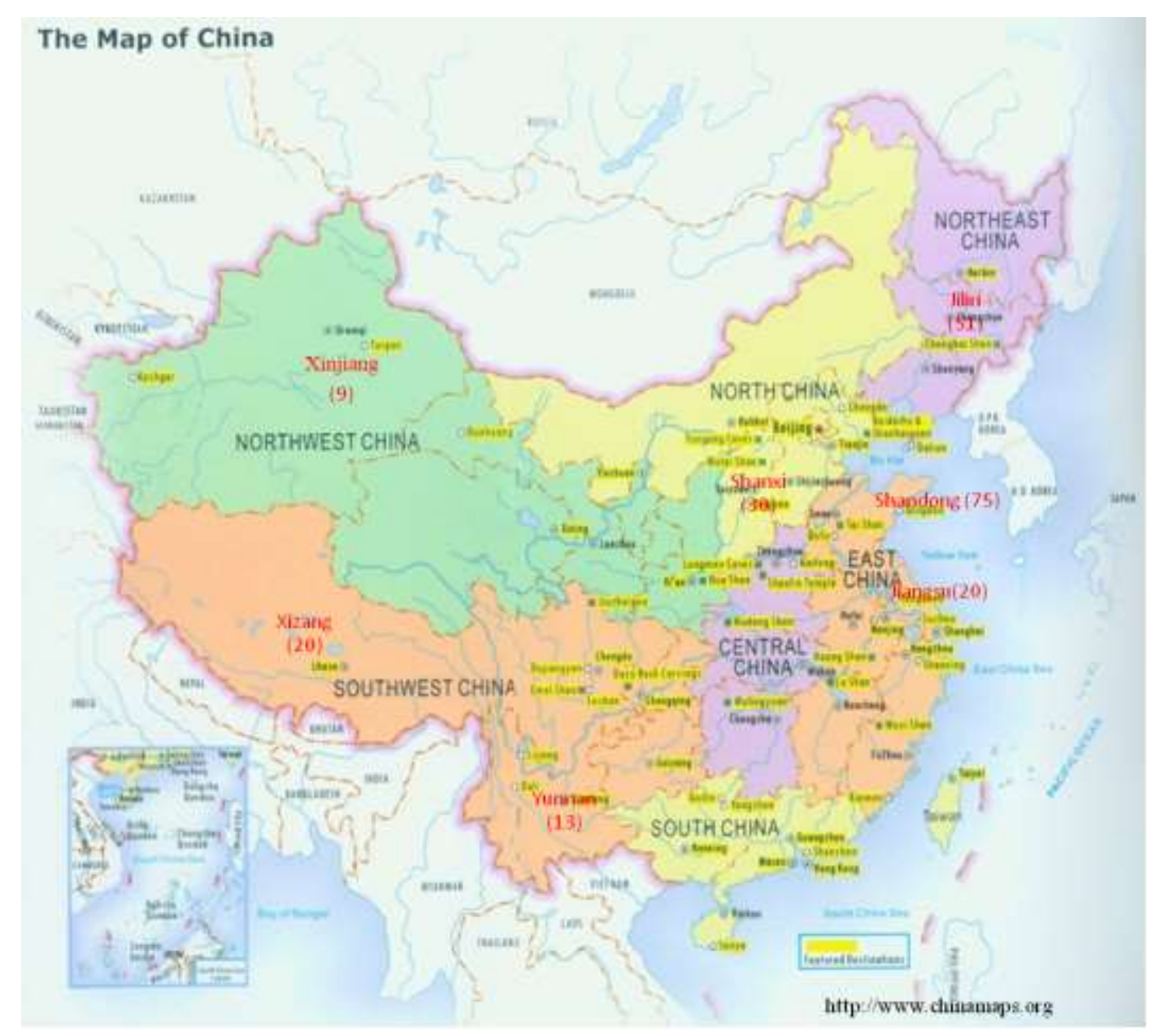

Fig. 1 Location of $218 \mathrm{E}$. coli strains isolated from China.

The number in red brackets stands for the quantity of E. coli strains obtained.

\section{Pathogenic gene detection}

All isolates were tested for the presence of pathogenic genes (eae-EPEC, stx-STEC, est-ETEC, elt-ETEC, ipaH-EIEC, aggR-EAEC) by multiplex PCR assay according to method described earlier [2]. DNA was prepared from overnight grown culture by boiling method. The procedure was advisably modified as follow. Multiplex PCR reaction system was carried out with a $25 \mu \mathrm{l}$ mixture containing Master Mix, DNA template, and six combined primers. The PCR program was denatured at $95^{\circ} \mathrm{C}$, annealed at $52^{\circ} \mathrm{C}$ and extended at $72^{\circ} \mathrm{C}$ for $35 \mathrm{cycles}$. PCR products were then electrophoresed on a agarose gel (AmpliSize; Bio-Rad Laboratories) and visualized by UV transillumination. Quality control E. coli strains of EPEC, STEC, ETEC, EIEC, and EAEC were from Chinese Center for Disease Control and Prevention.

\section{PCR for virulence genes}

All the above DNA extracts were also detected for the presence of Episomal outer membrane protease gene (ompT), Shiga-toxin gene (stx), Episomal increased serum survival gene (iss), Periplasmic chaperone (fimC), Salmochelin siderophore receptor gene (iroN), Putative avian hemolysin (hlyF) and Aerobactin siderophore receptor gene (iutA) by PCR as protocol of Timothy J et al. [11] and Jeong et al. [12]. 
Table 1 the primer sequences and amplicon size of virulence genes

\begin{tabular}{|c|c|c|c|}
\hline Gene & Primer sequence & Amplicon size & Reference \\
\hline ompT & $\begin{array}{l}\text { F: 5'-ATCTAGCCGAAGAAGGAGGC-3' } \\
\text { R: 5'-CCCGGGTCATAGTGTTCATC-3 }\end{array}$ & $496 \mathrm{bp}$ & $\begin{array}{l}\text { Timothy et } \\
\text { al., } 2008\end{array}$ \\
\hline Stx2 & $\begin{array}{l}\text { F: 5'-CTTCGGTATCCTATTCCCGG-3' } \\
\text { R: 5'-GGATGCATCTCTGGTCATTG-3 }\end{array}$ & $482 \mathrm{bp}$ & $\begin{array}{l}\text { Jeong et al., } \\
2012\end{array}$ \\
\hline iss & $\begin{array}{l}\text { F: 5'-AGCAACCCGAACCACTTGATG-3' } \\
\text { R: 5'-TAATAAGCATTGCCAGAGCGG-3 }\end{array}$ & $323 b p$ & $\begin{array}{l}\text { Timothy et } \\
\text { al., } 2008\end{array}$ \\
\hline $\operatorname{fimC}$ & $\begin{array}{l}\text { F: 5'-GGAAATAACATTCTGCTTGC-3' } \\
\text { R: 5'-TTTGTTGCATCAAGAATACG-3 }\end{array}$ & $288 b p$ & $\begin{array}{l}\text { Timothy et } \\
\text { al., } 2008\end{array}$ \\
\hline iron & $\begin{array}{l}\text { F: 5'-AAGTCAAAGCAGGGGTTGCCCG-3' } \\
\text { R: 5'-GACGCCGACATTAAGACGCAG-3 }\end{array}$ & $553 b p$ & $\begin{array}{l}\text { Timothy et } \\
\text { al., } 2008\end{array}$ \\
\hline hlyF & $\begin{array}{l}\text { F: 5'-GGCGATTTAGGCATTCCGATACTC-3' } \\
\text { R: 5'-ACGGGGTCGCTAGTTAAGGAG-3 }\end{array}$ & $450 \mathrm{bp}$ & $\begin{array}{l}\text { Timothy et } \\
\text { al., } 2008\end{array}$ \\
\hline iutA & $\begin{array}{l}\text { F: 5'-TTAATAGCACCCGGTACAAGCAGG-3' } \\
\text { R: 5'-CCTGACTCTTCAAAAGAGAAAAATTAC-3 }\end{array}$ & $302 b p$ & $\begin{array}{l}\text { Timothy et } \\
\text { al., } 2008\end{array}$ \\
\hline
\end{tabular}

\section{Antimicrobial susceptibility tests of E. coli strains}

All isolates detected with virulence genes positive above were subject to antimicrobial analysis. Susceptibility to antimicrobials was evaluated using broth microdilution method as described by the Clinical Laboratory Standards Institute (CLSI) guidelines (2012). The antimicrobials used for susceptibility test in this study included ampicillin (AMP), amoxicillin/clavulanic acid (A/C), tetracycline (TET), doxycycline (DOX), gentamicin (GEM), spectinomycin (SPT), sulfisoxazole (SF), trimethoprim-sulfamethoxazole (SXT), cefotaxime (CEF), ceftazidime (CAZ), florfenicol (FFC), enrofloxacin (ENR), ofloxacin (OFL), colimycin (CL) and meropenem (MEM). E. coli ATCC 25922 was used as positive control. The results were interpreted using CLSI breakpoints [13].

\section{Pulsed-field gel electrophoresis}

PFGE of the E. coli strains were performed according to non-0157 STEC subtyping protocol (www.pulsenetinternational.org) with few modifications [4]. The bacteria genomic DNA was digested with $50 \mathrm{U}$ of Xba I (Takara, China) at $37^{\circ} \mathrm{C}$ for $3 \mathrm{~h}$. Xba I-digested Salmonella enterica serovar Braenderup $\mathrm{H} 9812$ was used as the controlled DNA marker, PFGE was repeated twice to determine reproducibility. For un-typed isolates, 50 $\mu \mathrm{M}$ thiourea (Sigma, USA) was added to the $0.5 \times$ TBE buffer prior to PFGE running as described by Römling and Tümmler [14]. A contour-clamped homogenous electric field apparatus CHEF-Mapper (Bio-Rad, USA) was used for chromosome separation. The pulse time was ramped from $2.16 \mathrm{~s}$ to $54.17 \mathrm{~s}$ over $19 \mathrm{~h}$ at $6.0 \mathrm{~V} / \mathrm{cm}, \mathrm{Gel}$ images were captured with a Gel Documentation 2000 software (Bio-Rad, USA) and converted to Tiff files, then analyzed using BioNumerics software (Applied Maths Belgium). 


\section{Statistical analysis}

Statistical analysis was conducted by using SPSS 17.0. The difference of drug resistance was analyzed by oneway ANOVA test, $\mathrm{P}<0.05$, significant difference; $\mathrm{P}>0.05$, no significant difference.

\section{Results}

\section{Pathogenic potentials among $248 \mathrm{E}$. coli isolates}

In order to study the prevalence of pathogenic E. coli, we categorized the E. coli isolates into different pathothypes according to the PCR results for pathogenic marker genes: eae, stx, est, elt, ipaH, and aggR. Six $(2.42 \%, 6 / 248)$ isolates were identified as pathogenic E. coli which carried est and/or elt gene, and all these pathogenic strains were classified as ETEC. Of the six pathogenic strains, four strains were from Shandong Province and the other two strains from Shanxi Province and Algeria respectively. No EPEC, STEC, EAEC or EIEC strains were detected in this study.

\section{Prevalence of virulence genes}

Seven virulence genes were tested to all the E. coli strains by PCR. These virulence gene frequencies among the E. coli strains were exhibited in Table 2 . Gene stx2 was only detected in two isolates $(2.7 \%, 2 / 75)$ from Shandong Province. Both ompT and iroN virulence gene were detected from isolates of Tibet, however, stx2, iss, fimC, hlyF, and iutA were all free among Tibet isolates, indicating their lower pathogenic characters.

Importantly, nearly all isolates from Algeria carried seven virulence genes. The frequency of six virulence genes, ompT, iss, fimC, iroN, hlyF, and iutA was high in the isolates from Shanxi, Jiangsu Yunnan, and Xinjiang of China (Table 2).

Table 2 prevalence of virulence genes among the $E$. coli strains

\begin{tabular}{|c|c|c|c|c|c|c|c|c|c|c|}
\hline \multirow{2}{*}{ Region } & \multirow{2}{*}{$\begin{array}{l}\text { No. of } \\
\text { isolates } \\
(n=248)\end{array}$} & \multirow{2}{*}{$\begin{array}{l}\text { No.(\%) } \\
\text { isolates } \\
\text { positive } \\
\text { virulence } \\
\text { gene }\end{array}$} & \multirow{2}{*}{$\begin{array}{l}\text { of } \\
\text { for }\end{array}$} & \multicolumn{7}{|c|}{ Virulence gene $\left(n^{a}\right)$} \\
\hline & & & & $\begin{array}{l}\text { omp } \\
\mathrm{T}\end{array}$ & $\begin{array}{l}\text { stx } \\
2\end{array}$ & iss & fimc & iroN & hlyF & iutA \\
\hline Shandong & 75 & $26(34.7)$ & & 11 & 2 & 14 & 22 & 20 & 14 & 15 \\
\hline Shanxi & 30 & $30(100)$ & & 14 & 0 & 25 & 19 & 30 & 21 & 30 \\
\hline Jiangsu & 20 & $15(75.0)$ & & 6 & 0 & 11 & 11 & 10 & 11 & 10 \\
\hline Yunnan & 13 & $12(92.3)$ & & 8 & 0 & 8 & 11 & 9 & 9 & 10 \\
\hline Jilin & 51 & $17(33.3)$ & & 7 & 0 & 7 & 16 & 11 & 11 & 9 \\
\hline Tibet & 20 & $4(20.0)$ & & 2 & 0 & 0 & 0 & 3 & 0 & 0 \\
\hline Xinjiang & 9 & $7(77.8)$ & & 3 & 0 & 6 & 5 & 7 & 7 & 6 \\
\hline Algeria & 30 & $30(100)$ & & 20 & 1 & 17 & 20 & 19 & 19 & 22 \\
\hline
\end{tabular}


${ }^{a}$ No. of single virulence gene of positive isolates in each province of China and Algeria.

\section{Antimicrobial Resistance}

Among the 248 isolates, 141 strains which carried one or more virulence genes were tested for antimicrobial studies, including $30 \mathrm{E}$. coli strains from Algeria. Of the $111 \mathrm{E}$. coli strains isolated from diseased or freshly died chickens in China, $97.3 \%(n=108)$ were resistant to tetracycline, followed by ampicillin $(96.4 \%, n=107)$, cefotaxime $(91.9 \%, n=102)$, enrofloxacin $(91 \%, n=101)$, ofloxacin $(90.1 \%, n=100)$. Only meropenem was much more sensitive to the isolates which the resistant strains was just $7.2 \%(n=8)$. Other drug resistant ratios were $64.9 \%(n=72)$ $\sim 87.4 \%(n=97)$, except for amoxicillin/clavulanic acid $(20.7 \%, n=23)$, colimycin $(22.5 \%, n=25)$ and ceftazidime $(25.2 \%, n=28)$. More than $97.3 \%(n=108)$ of the isolates were resistant to five or more kinds of antimicrobial agents, including two isolates from Shandong province resistant to all the fifteen kind of drugs tested. $98.2 \%$ $(n=109)$ of the isolates resist to more than three classes of antimicrobials, thus defined as multi-drug resistant (MDR).

There was significant difference among isolates with resistance against antimicrobial agents from different provinces (AMP $(P=0.002), A / C(P=0.000)$, DOX $(P=0.009)$, GEM $(P=0.018), S P T(P=0.000)$, SF $(P=0.000)$, SXT $(P=0.000)$, CEF $(P=0.000)$, CAZ $(P=0.000)$, FFC $(P=0.000)$, ENR $(P=0.000)$, OFL $(P=0.000), C L(P=0.000)$, MEM $(P=0.044))$ except tetracycline $(P=0.220)$. All isolates from Tibet were susceptible to most of the tested antibacterial agents except for tetracycline, doxycycline, and sulfisoxazole. Isolates from both Xinjiang and Yunnan exhibited high frequencies of antibacterial resistance (Table 3).

Table 3 Antimicrobial resistance of E. coli isolates from different regions

\begin{tabular}{|c|c|c|c|c|c|c|c|c|c|}
\hline Antimi- & Province, & $\%(n)$ & & & & & & Total & Algeria \\
\hline $\begin{array}{l}\text { crobials } \\
\text { a }\end{array}$ & $\begin{array}{l}\text { Shando } \\
\text { ng } \\
(26)\end{array}$ & $\begin{array}{l}\text { Shanxi } \\
\text { (30) }\end{array}$ & $\begin{array}{l}\text { Jiangs } \\
\mathrm{u} \\
(15)\end{array}$ & $\begin{array}{l}\text { Yunna } \\
\mathrm{n} \\
(12)\end{array}$ & $\begin{array}{l}\text { Jilin } \\
\text { (17) }\end{array}$ & $\begin{array}{l}\text { Tibet } \\
\text { (4) }\end{array}$ & $\begin{array}{l}\text { Xinjian } \\
\mathrm{g} \\
(7)\end{array}$ & (111) & (30) \\
\hline AMP & $96.2(25)$ & $\begin{array}{l}100(30 \\
)\end{array}$ & $\begin{array}{l}93.3(1 \\
4)\end{array}$ & $\begin{array}{l}100(12 \\
)\end{array}$ & $\begin{array}{l}100(17 \\
)\end{array}$ & $50(2)$ & $100(7)$ & $\begin{array}{l}96.4(107 \\
)\end{array}$ & $\begin{array}{l}96.7(2 \\
9)\end{array}$ \\
\hline $\mathrm{A} / \mathrm{C}$ & $11.5(3)$ & $16.7(5)$ & $0(0)$ & $66.7(8)$ & $23.5(4)$ & $50(2)$ & $14.3(1)$ & $20.7(23)$ & $23.3(7)$ \\
\hline TET & 100(26) & $\begin{array}{l}96.7(2 \\
9)\end{array}$ & $\begin{array}{l}86.7(1 \\
3)\end{array}$ & $\begin{array}{l}100(12 \\
)\end{array}$ & $\begin{array}{l}100(17 \\
)\end{array}$ & $\begin{array}{l}100(4 \\
)\end{array}$ & $100(7)$ & $\begin{array}{l}97.3(108 \\
)\end{array}$ & $\begin{array}{l}96.7(2 \\
9)\end{array}$ \\
\hline DOX & $57.7(15)$ & $50(15)$ & $\begin{array}{l}66.7(1 \\
0)\end{array}$ & $\begin{array}{l}100(12 \\
)\end{array}$ & $\begin{array}{l}70.6(1 \\
2)\end{array}$ & $\begin{array}{l}100(4 \\
)\end{array}$ & $100(7)$ & $67.6(75)$ & $\begin{array}{l}76.7(2 \\
3)\end{array}$ \\
\hline GEM & 73.1(19) & $\begin{array}{l}53.3(1 \\
6)\end{array}$ & $53.3(8)$ & $75(9)$ & $\begin{array}{l}82.4(1 \\
4)\end{array}$ & $0(0)$ & $85.7(6)$ & $64.9(72)$ & $26.7(8)$ \\
\hline SPT & $92.3(24)$ & $\begin{array}{l}56.7(1 \\
7)\end{array}$ & $\begin{array}{l}73.3(1 \\
1)\end{array}$ & $\begin{array}{l}100(12 \\
)\end{array}$ & $\begin{array}{l}82.4(1 \\
4)\end{array}$ & $0(0)$ & $100(7)$ & $76.6(85)$ & $\begin{array}{l}93.3(2 \\
8)\end{array}$ \\
\hline SF & 73.1(19) & $\begin{array}{l}96.7(2 \\
9)\end{array}$ & $\begin{array}{l}86.7(1 \\
3)\end{array}$ & $\begin{array}{l}100(12 \\
)\end{array}$ & $52.9(9)$ & $\begin{array}{l}100(4 \\
)\end{array}$ & $100(7)$ & 83.8(93) & $80(24)$ \\
\hline
\end{tabular}




\begin{tabular}{|c|c|c|c|c|c|c|c|c|c|}
\hline SXT & $100(26)$ & $\begin{array}{l}73.3(2 \\
2)\end{array}$ & $\begin{array}{l}86.7(1 \\
3)\end{array}$ & $\begin{array}{l}100(12 \\
)\end{array}$ & $\begin{array}{l}100(17 \\
)\end{array}$ & $0(0)$ & $100(7)$ & 87.4(97) & $\begin{array}{l}96.7(2 \\
9)\end{array}$ \\
\hline CEF & $96.2(25)$ & $\begin{array}{l}100(30 \\
)\end{array}$ & $\begin{array}{l}86.7(1 \\
3)\end{array}$ & $\begin{array}{l}91.7(1 \\
1)\end{array}$ & $\begin{array}{l}94.1(1 \\
6)\end{array}$ & $0(0)$ & $100(7)$ & $\begin{array}{l}91.9(102 \\
)\end{array}$ & $\begin{array}{l}43.3(1 \\
3)\end{array}$ \\
\hline CAZ & $30.8(8)$ & $0(0)$ & 26.7(4) & $50(6)$ & $23.5(4)$ & $0(0)$ & $85.7(6)$ & $25.2(28)$ & $\begin{array}{l}43.3(1 \\
3)\end{array}$ \\
\hline FFC & $96.2(25)$ & $\begin{array}{l}100(30 \\
)\end{array}$ & $\begin{array}{l}66.7(1 \\
0)\end{array}$ & $\begin{array}{l}100(12 \\
)\end{array}$ & $\begin{array}{l}64.7(1 \\
1)\end{array}$ & $0(0)$ & $0(0)$ & $79.3(88)$ & $30(9)$ \\
\hline ENR & $100(26)$ & $\begin{array}{l}96.7(2 \\
9)\end{array}$ & $\begin{array}{l}66.7(1 \\
0)\end{array}$ & $\begin{array}{l}100(12 \\
)\end{array}$ & $\begin{array}{l}100(17 \\
)\end{array}$ & $0(0)$ & $100(7)$ & 91(101) & $\begin{array}{l}93.3(2 \\
8)\end{array}$ \\
\hline OFL & $100(26)$ & $\begin{array}{l}96.7(2 \\
9)\end{array}$ & $\begin{array}{l}66.7(1 \\
0)\end{array}$ & $\begin{array}{l}100(12 \\
)\end{array}$ & $\begin{array}{l}94.1(1 \\
6)\end{array}$ & $0(0)$ & $100(7)$ & $\begin{array}{l}90.1(100 \\
)\end{array}$ & $90(27)$ \\
\hline $\mathrm{CL}$ & 26.9(7) & $0(0)$ & 26.7(4) & $66.7(8)$ & $0(0)$ & $0(0)$ & $85.7(6)$ & $22.5(25)$ & $\begin{array}{l}53.3(1 \\
6)\end{array}$ \\
\hline MEM & $11.5(3)$ & $0(0)$ & $0(0)$ & $0(0)$ & $23.5(4)$ & $0(0)$ & $14.3(1)$ & $7.2(8)$ & $6.7(2)$ \\
\hline
\end{tabular}

${ }^{a} A M P$, ampicillin; A/C, amoxicillin/clavulanic acid; TET, tetracycline; DOX, doxycycline; GEM, gentamicin; SPT, spectinomycin; SF, sulfisoxazole; SXT, trimethoprim-sulfamethoxazole; CEF, cefotaxime; CAZ, ceftazidime; FFC, florfenicol; ENR, enrofloxacin; OFL, ofloxacin; $C L$, colimycin and MEM, meropenem.

It was noteworthy that we found nearly all the E. coli isolates, including the thirty strains from Algeria, were MDR (Table 4, Figure 2). These data therefore reminds us that veterinary clinical irregular use of antimicrobial agents is already a very serious problem not only in China, but also in the African countries, even the world.

Table 4 MDR distribution in different regions

\begin{tabular}{|c|c|c|c|c|c|c|c|c|c|}
\hline \multirow{2}{*}{$\begin{array}{l}\text { Drug } \\
\text { classes }\end{array}$} & \multicolumn{7}{|c|}{ Province, $\mathrm{n}^{\mathrm{b}}(\%)$} & \multirow{2}{*}{$\begin{array}{l}\text { Total } \\
(111)\end{array}$} & \multirow{2}{*}{$\begin{array}{l}\text { Algeria } \\
(30)\end{array}$} \\
\hline & $\begin{array}{l}\text { Shando } \\
\mathrm{ng} \\
(26)\end{array}$ & $\begin{array}{l}\text { Shanxi } \\
\text { (30) }\end{array}$ & $\begin{array}{l}\text { Jiangs } \\
\mathrm{u} \\
(15)\end{array}$ & $\begin{array}{l}\text { Yunna } \\
\mathrm{n} \\
(12)\end{array}$ & $\begin{array}{l}\text { Jilin } \\
(17)\end{array}$ & $\begin{array}{l}\text { Tibet } \\
\text { (4) }\end{array}$ & $\begin{array}{l}\text { Xinjian } \\
\mathrm{g} \\
(7)\end{array}$ & & \\
\hline 2 & 0 & 0 & 0 & 0 & 0 & $2(50)$ & 0 & $2(1.8)$ & \\
\hline $3^{a}$ & 0 & 0 & 0 & 0 & 0 & $2(50)$ & 0 & $2(1.8)$ & $1(3.3)$ \\
\hline 4 & 0 & 0 & $1(6.7)$ & 0 & 0 & 0 & 0 & $1(0.9)$ & 0 \\
\hline 5 & 0 & 0 & $2(13.3)$ & 0 & $1(5.9)$ & 0 & 0 & $3(2.7)$ & $7(23.3)$ \\
\hline 6 & $3(11.5)^{c}$ & $8(26.7)$ & $6(40)$ & 0 & $6(35.3)$ & 0 & $1(14,3)$ & $24(21.6)$ & $7(23.3)$ \\
\hline 7 & $16(61.5)$ & $\begin{array}{l}22(73 . \\
3)\end{array}$ & $5(33.3)$ & $5(41.7)$ & $\begin{array}{l}10(58 . \\
8)\end{array}$ & 0 & $6(85.7)$ & $64(57.7)$ & $12(40)$ \\
\hline 8 & $7(26.9)$ & 0 & $1(6.7)$ & $7(58.3)$ & 0 & 0 & 0 & $15(13.5)$ & $3(10)$ \\
\hline
\end{tabular}




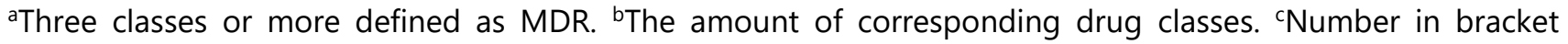
representative percent of regional strains.

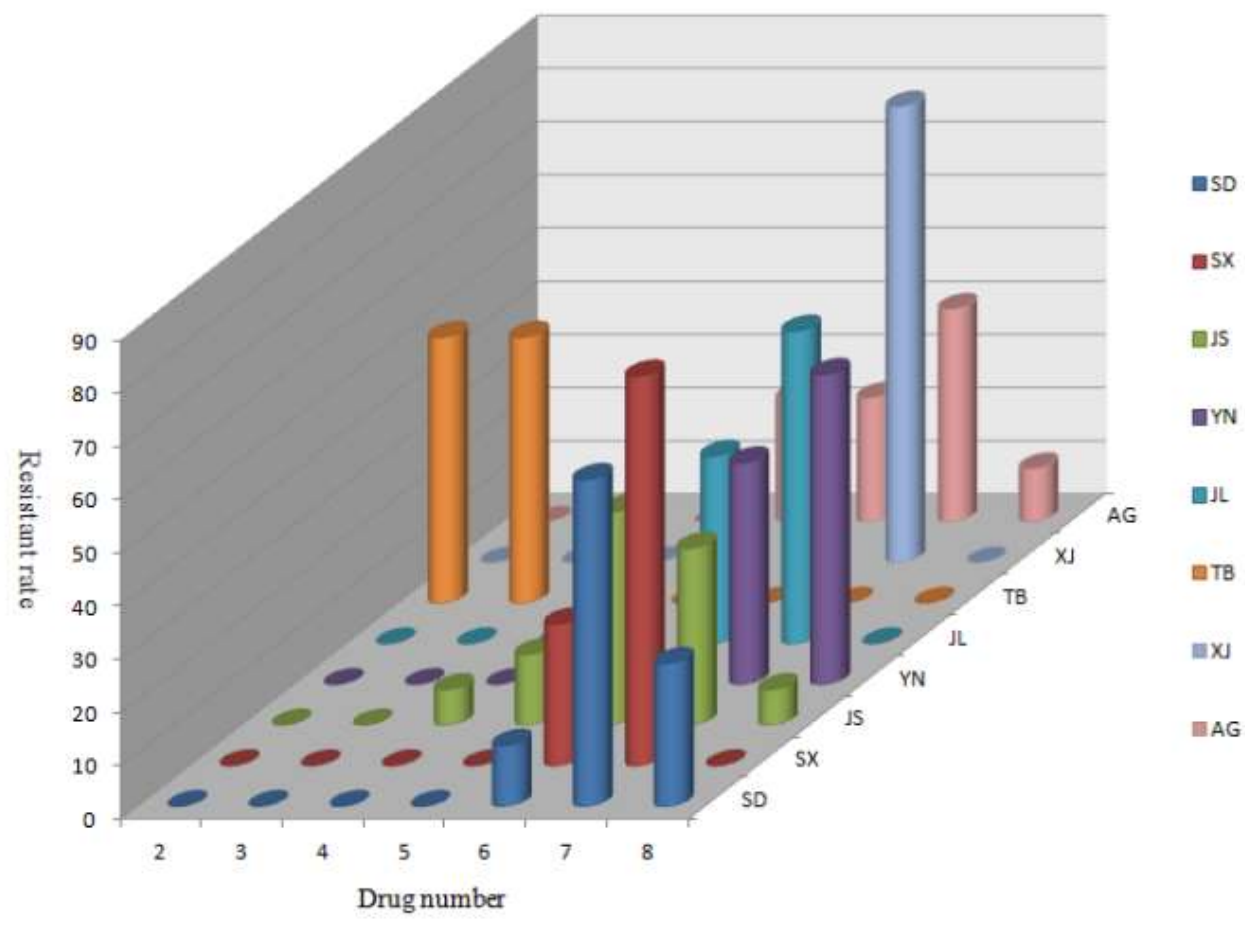

Fig. 2 Prevalence of multidrug resistance in $248 \mathrm{E}$. coli isolates. Abbreviations for antibiotics are SD, Shandong; SX, Shanxi; JS, Jiangsu; YN, Yunnan; JL, Jilin; TB, Tibet; XJ, Xinjiang; Total, Total of China strains; AG, Algeria.

\section{PFGE fingerprinting}

$157 \mathrm{E}$. coli isolates, including 141 strains with antimicrobial resistance analysis and 14 other E. coli strains with no virulence gene from Tibet, were analyzed by PFGE using enzyme Xba I. The result showd that 157 isolates could be divided at a similarity of $60 \%$ or greater. There were 134 clearly distinguishable patterns which demonstrated a high level of genetic diversity among these isolates, in which, 11 PFGE typing are clustered by 2 to 6 strains respectively, the same fingerprint strains gathered in a cluster, it is believed that these strains may be from the same clone. The 22 strains from Shanxi are corresponding to eight different PFGE typing, which shows that E. coli is highly similar in Shanxi Province. An UPGMA dendrogram was constructed in Figure 3. 


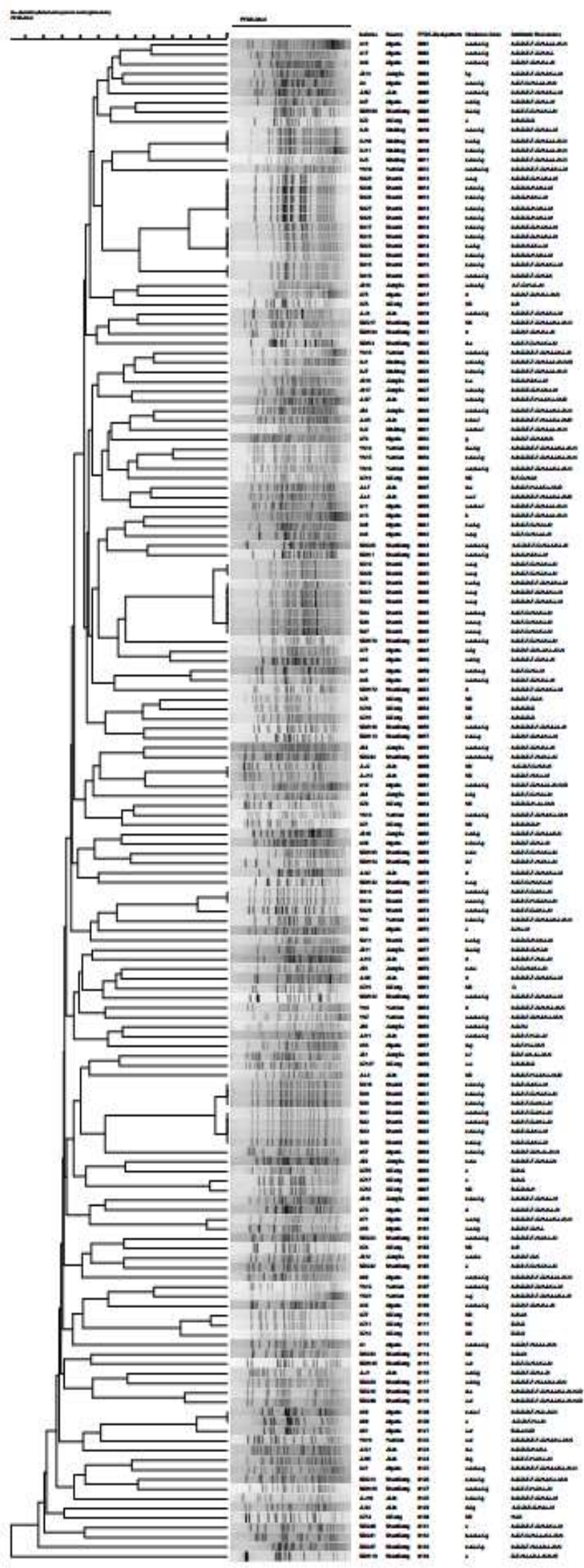

Fig. 3. Dendrogram of PFGE profiles of $157 \mathrm{E}$. coli isolates from diseased or freshly died chickens. 
PFGE patterns and the corresponding dendrogram for 157 isolates obtained in the present study are depicted. Displayed on the right-hand side are Isolates, Source, PFGE-Pattern, virulence gene, and antibiotic resistance. Abbreviations for antibiotics are: A, Ampicillin; B, Auge door-keeper; C, Tetracycline; D, Doxycycline; E, Gentamicin; F, Spectinomycin; G, Sulfisoxazole; H, Trimethoprim-sulfamethoxazole; I, Cefotaxime; J,Ceftazidime; K, Florfenicol; L, Enrofloxacin; M, Ofloxacin ; N, Polymyxin ; O, Meropenem.

"Xizang" in the right "Source" column also named Tibet.

\section{Discussion}

Avian origin E.coli is the mainly etiologic agent of avian colibacillosis. It may cause a large number of chicken diseased and sometimes cause extensive mortality in poultry flocks by primary or secondary infection of E.coli, which lead to huge economic losses in some epidemic areas. Ordinarily, E.coli strains isolated from such tissues as spleen, heart or liver are most potentially pathogenic. However, in this study, of all 218 E.coli isolates from different regions of China, we only confirmed five strains $(2.29 \%, 5 / 218)$ as ETEC which carried pathogenic marker gene est or elt.

The prevalence of toxin-encoding virulence genes, namely ompT, stx2, iss, fimC, iroN, hlyF, and iutA, was further evaluated (Table 2). The similar frequency of virulence genes showed in isolates from Algeria and some provinces of China, it may be illustrate that E. coli strains isolated from poultry population of both Algeria and China has similar evolution process. The positive rate for virulence gene of isolates from Shanxi was $100 \%$, followed by Yunnan (92.3\%), Xinjiang (77.8\%) and Jiangsu (75.0\%). Shandong (34.7\%), Jilin (33.3\%) and Tibet (20.0\%) revealed relatively lower virulence gene carried rate. In addition, except two strains $(2.7 \%, 2 / 75)$ from Shandong province hosted stx2 gene, none of other 216 strains harbored it. Shiga toxins play a main role in intense inflammatory reaction and may account for the ability of STEC strains to cause serious illness in both affected human and suffered animals. These toxins were expressed by stx genes which constitute two major subfamilies: stx 1 and stx2 [15]. Though we obtained stx2 gene in two isolates from Shandong province (Table 2), no stx-based STEC was confirmed.

Interestingly, in Tibet isolates, only ompT $(10 \%, 2 / 20)$ and iroN $(15 \%, 3 / 20)$ were detected among the seven virulence genes at present research, which is the first report of virulence status on avian origin E. coli from Tibet Autonomous region of China. Moreover, further analysis should be implemented if the extensive difference with other region isolates in carrying virulence genes was associated with plateau climate factors.

Mildly variation of PFGE genotypes for E. coli was observed in this report. Their overall similarity value was about 60\% 100\%. 157 E. coli isolates were divided into 134 PFGE types, in which, 11 PFGE types are clustered by the 2 6 same fingerprint strains, it is believed that these strains may be from the same clone. Dai et al. [16] studied on 16 strains from different farms multi-resistant source of chicken E. coli PFGE classification analysis, 16 different belt type, which fully embodies the polymorphism distribution of E. coli.

All isolates of mapping results show PFGE. The 22 strains of Shanxi isolates are corresponding to eight different PFGE typing. This relationship shows that E. coli is highly similar in Shanxi Provence. It also shows that between a horizontal distribution and vertical transmission of isolates, thus combining PFGE classification method is helpful to find popular advantage of molecular features determine the region characteristics of the strain.

In this study, the resistance of $111 \mathrm{E}$. coli isolates to 15 antimicrobials that represent eight antimicrobial drug 
types was also examined, as well as $30 \mathrm{E}$. coli strains from Algeria. First-line antimicrobials, such as tetracycline, ampicillin, cefotaxime, enrofloxacin, ofloxacin, trimethoprim-sulfamethoxazole and sulfisoxazole, exhibited lower activity against the Escherichia coli isolates of China. Particularly, the resistance of Yunnan strains to ampicillin, tetracycline, doxycycline, spectinomycin, sulfisoxazole, trimethoprim-sulfamethoxazole, cenrofloxacin, and ofloxacin reached $100 \%$. While the resistance of Xinjiang strains to the above antimicrobial agents was almost consistent with Yunnan strains, except for florfenicol which was $100 \%$ activity to Yunnan strains but $0 \%$ to Xinjiang isolates.

Moreover, we found that nearly all E.coli isolates $(98.2 \%$, 109/111) were MDR except for two isolates from Tibet in southwestern China, which were also resistant to two of eight class drugs in 15 antimicrobials tested. Akin higher frequency of resistance against multidrug in clinical $\mathrm{E}$. coli isolates from poultry was also observed in other studies in China $[7,17,18]$. In Shandong province, our retrospective study revealed that the MDR rate of E.coli strains isolated from broiler population during 2000-2012 reached up to $100 \%$, with at least 5 to 12 classes tolerance [19]. MDR rate in 2014 also attained $98.86 \%$ among the tested 438 strains of avian origin E.coli in our laboratory [17]. Similarly, the E.coli isolates MDR rate of Algeria also came up to $100 \%$ (Table 3). These results suggested that veterinary clinical irregular use or abuse of antimicrobial agents has already become an increasingly serious issue not only in China but also in western African countries.

It is without any surprising that $\mathrm{E}$. coli isolates from Tibet was much more sensitive to most antimicrobial agents. Only three antimicrobial drug types of the tested E.coli strains were exhibited in this study. Unfortunately, few studies of antimicrobials on poultry origin E. coli isolated from this region were reported in the past. However, 46.7 $80.0 \%$ of E.coli isolates identified from the fresh faeces of yaks was found to show highly multi-drug resistance capabilities (MDR) in Tibet $[20,21]$. Furthermore, the Tibet strains in this study was much more resistant to tetracycline (100\%), doxycycline (100\%), sulfisoxazole (100\%), ampicillin (50\%) and amoxicillin/clavulanic acid (50\%), but high sensitivity to gentamicin $(0 \%)$, spectinomycin $(0 \%)$, trimethoprim-sulfamethoxazole $(0 \%)$, cefotaxime $(0 \%)$, ceftazidime $(0 \%)$, florfenicol $(0 \%)$, enrofloxacin $(0 \%)$, ofloxacin $(0 \%)$, meropenem $(0 \%)$ and colimycin (0\%). Nevertheless, the isolates of Yak origin showed different level of resistance to ampicillin (90.9\%), doxycycline (90.9\%), tetracycline (81.8\%), cefotaxime (79\%), gentamicin (63.4\%) and trimethoprimsulfamethoxazole (54\%) $[20,21]$. These difference of antimicrobials maybe connect with a large amount of yaks pasture and few poultry farming in Tibet autonomous region.

In conclusion, this study provides the first comparable report of properties of poultry origin E. coli in different representative regions of China and western African country, Algeria. Our findings enrich the knowledge of avian origin E. coli strains virulence gene prevalence and characteristics both in China and Algeria. Both the poultry origin E. coli from China and Algeria exhibited either high frequencies of anti-drug resistance or high rates of virulence genes carrying. These findings indicate that clinical irregular use or abuse of antimicrobials has already been a public concern not only in China but also in western African countries. However, much more isolates should be investigated in western China and western African countries so as to further comprehensive evaluate the prevalence properties of clinical E. coli isolates.

\section{Conclusions:}

1. Six (2.42 \%) avian origin E. coli were identified as pathogenic E. coli.

2. The frequency of 7 virulence genes was high in the isolates from Algeria and the other six provinces of China except Tibet. 
3. Most isolates from China and all from Algeria resist to more than three classes of antimicrobials.

4. Isolates from Tibet were susceptible to most antibacterials.

5. PFGE genotype of isolates demonstrated a high level of genetic diversity among isolates from China and Algeria.

Data Availability: Readers send e-mail to corresponding author asking for the data underlying the finding of this study.

Conflicts of interest: The authors declare no conflicts of interest.

\section{Funding Statement:}

This work was funded by the National Key Research and Development Program of China [grant number 2018YFD0500505] and the National Special Project for Risk Assessment of Quality \& Safety of Agricultural Products [grant number GJFP201800703], as well as the Project of Science \& Technology Development Planning of Shandong Province [grant number 2014GSF120006].

\section{Acknowledgments:}

Many thanks to Prof. Song Gao in College of Veterinary Medicine of Yangzhou University, Prof. Linbo Zhang in College of Life Science of Jilin Agriculture University, Associate Prof. Xia Sun in Shandong Vocational Animal Science and Veterinary College, Mr. Gang Zhang in Yunnan Academy of Animal Husbandry and Prof. Yan Li in Center for Animal Diseases Prevention and Control of Xinjiang Corps for their help of bacteria strains preisolation and pre-identification, as well as Dr. Biao Kan in Chinese Center for Disease Control and prevention for PFGE analysis in this study.

\section{References}

1. Griffin P. M., Tauxe R. V. 1991. The epidemiology of infections caused by Escherichia coli O157: H7 other enterohemorrhagic E. coli and the associated hemolytic uremic syndrome. Epidemiol. Rev. 13: 60-98.

2. Toma C., Lu Y., Higa N., Nakasone N., Chinen I., Baschkier A., Rivas M., Iwanaga M. I. 2003. Multiplex PCR Assay for Identification of Human Diarrheagenic Escherichia coli. J. Clin. Microbiol. 41(6): 2669-2671.

3. Lu Y., Zhao H. Y., Sun J., Liu Y. Q., Zhou X. P., Beier R. C., Wu G. J. 2014. Characterization of Multidrug-Resistant Salmonella enteric Serovars Indiana and Enteritidis from Chickens in Eastern China. PLOS ONE 9(5): e96050.

4. Gai W. Y., Wang J. W., Wang J., Cui Z. G., Qu Z. N., Hong J., Cui J. H., Du X. L., Huang X. M., Cao X. M., Zhao J. M. 2015. Molecular classification and drug resistance analysis of Escherichia coli isolated from poultry in China. International J. Clin. Exp. Med. 8(1): 836-844.

5. Goering R. V., Winters M. A. 1992. Rapid method for epidemiological evaluation of gram-positive cocci by field inversion gel electrophoresis. J. Clini. Microbiol. 30: 577-580.

6. Su J. Y., Shi L., Yang L. S., Xiao Z. H., Li X. H., Yamasaki S. 2006. Analysis of integrons inclinical isolates of Escherichia coli in China during the last 6 years. FEMS Microbiol. Letters 254: 75-80.

7. Chen X., Zhang W., Yin J., Zhang N., Geng S., Zhou X., Wang Y., Gao S., Jiao X. 2014. Escherichia coli isolates from sick chickens in China: changes in antimicrobial resistance between 1993 and 2013. The Vet. J. 202(1): 112-115. 
8. Wu H., Xia S. B., Bu F. Y., Qi J., Liu Y. Q., Xu H. 2015. Identification of integrons and phylogenetic groups of drug-resistant Escherichia coli from broiler carcasses in China. Inter. J. Food Microbiol. 211: 51-56.

9. Lounis M., Zhao G., Li Y. H., Gao Y. B., Rachid K., Mustapha O., Wang J. W., Karine O. Virulence traits of avian pathogenic (APEC) and fecal (AFEC) E. coli isolated from broiler chickens in Algeria. Tropical Anim. Health and Produ. 2018, 50, 547-553.

10. Zhao G., Song X., Zhao J. M., Li Y. H., Wang J., Huang X. M., Qu Z. N., Wang Y. D., Yan S. G., Wang J. W. 2016. Isolation, Identification, and Characterization of Foodborne Pathogens Isolated from Egg Internal Contents in China. J. Food Prot. 79(12): 2107-2112.

11. Timothy J. J., Yvonne W., Curt D., Sara J. J., Sandra C. R., Lisa K. N. 2008. Identification of Minimal Predictors of Avian Pathogenic Escherichia coli Virulence for Use as a Rapid Diagnostic Tool. J. clin. microbial. 46(12): 3987-3996.

12. Jeong Y. W., Kim T. E., Kim J. H., Kwon H. J. 2012. Pathotyping avian pathogenic Escherichia coli in Korea. J. Vet. Sci. 13(2): 145-452.

13. [CLSI] Clinical and Laboratory Standards Institute. 2013. Performance standards for antimicrobial susceptibility testing, Twenty-second informational supplement. CLSI document M100-S23, Wayne, PA: Clinical and Laboratory Standards Institute.

14. Römling U., Tümmler B. 2000 . Achieving $100 \%$ typeability of Pseudomonas aeruginosa by pulsed-field gel electrophoresis. J. Clin. Microbiol. 38: 464-465.

15. Gyles C. L. 2007. Shiga toxin-producing Escherichia coli: An overview. J.Anim. Sci. 85(13): E45-E62.

16. Dai L., Lu L. M., Wu C.M., Li B. B., Huang S. Y., Wang S. C., Qi Y. H., Shen J. Z. 2008. Characterization of antimicrobial resistance among Escherichia coli isolates from chickens in China between 2001 and 2006. FEMS Microbiol. Letters 286: 178-183.

17. Qu Z. N., Hu, X. Y., Wang, J., Zhao S. J., Li Y. Q., Huang X. M., Wang J. W. 2014. Antibiotic Resistance Investigation and Phylogenetic Groups Analysis of Chicken Originated E. coli Strains from Different Province. Chin. J. Vet. Drug 48(9): 4-8.

18. Yassin A. K., Gong J. S., Kelly P., Lu G. W., Guardabassi L., Wei L. J., Han X. G., Qiu, H. X., Price S., Cheng D. R., Wang C. M. 2017. Antimicrobial resistance in clinical Escherichia coli isolates from poultry and livestock, China. PLOS ONE 12(9): e0185326.

19. Gai W. Y., Wang J., Qu Z. N., Wang J. W., Huang X. M., Wang Y. D., Zhao S. J., Hong, J. 2015. Molecular Classification and drug resistance analysis of Escherichia coli in Shandong Province. Chin. J. of Food Hygiene 27(2): 109-114.

20. Gong G., Wang G., La Z., Xing D. Y., Suo, L. 2014. Study on antibiotic resistance of Yak E. coli. Chine. J. Vet. Med. 50(8): 80-82.

21. Yang X., Zou W., Zeng J., Xie S., An T., Luo X., Chen D., Feng L., Cheng G., Cai R., Huang Q., Wang H. 2017. Prevalence of antimicrobial resistance and integron gene cassettes in Escherichia coli isolated from yaks (Poephagus grunniens) in Aba Tibetan Autonomous Prefecture, China. Microbial Pathog. 111: 274-279. 